\title{
The perceptions of primary school teachers on the causes of high failure rate at grade 7 level in the Shiselweni region of Swaziland
}

\author{
Patience Lungile Maphalala, Makondo Davison (Ph.D) \\ (Educational Foundations and Management, University of SwazilandPrivate Bag 4 Kwaluseni, Swaziland. \\ Department of Education, University of Swaziland, Private Bag Matsapa, Swaziland
}

\begin{abstract}
Studies have revealed that for the past four years a huge number of the grade seven learners in the Shiselweni region of Swaziland have performed extremely badly in the external examination compared to its counterparts, the Hhohho, Manzini and Lubombo regions. This study aims to investigate the perceptions of primary school teachers on the causes of high failure rate at grade seven level in the Shiselweni region of Swaziland. The study was qualitative with a phenomenological approach. Participants were 12 teachers representing grade seven teachers $(n=6)$ and school principals $(n=6)$. Data were collected through in-depth interviews, focus groups and documents analysis. The major research findings revealed that the causes of the high failure rate was not a single factor but a multiple of factors from the home environment, the school environment, the teachers, the pupils and as well as the parental factors. The findings of the study concluded that environmental factors, teacher factors, pupils factors and parental factors are the causes of high failure rate at Grade seven level in the Shiselweni region of Swaziland. It was recommended that the Ministry of Education should organise in-service workshop for teachers on the importance of educational policies. The teachers should be equipped with pedagogical competences to improve the academic performance of the pupils.
\end{abstract}

Keywords:- High failure rate, perceptions, phenomenological study, Shiselweni region, Swaziland Education and Training Sector Policy.

\section{INTRODUCTION}

Education is regarded by many people as the cornerstone for economic and social development in Swaziland. Like most developing countries, Swaziland was faced with many serious educational problems immediately after independence in 1968. These problems ranged from the poor quality education, few and unevenly distributed schools, inadequate learning and teaching resources, high dropout, repeat and failure rates, serious shortage of trained teachers, and inappropriate and highly academic curricula at both primary and secondary school levels (Magagula, 1990). There are hues and cries among the stakeholders in education over the growing rate of failure in Swaziland Primary Certificate (SPC) examinations in recent times. For the past four years the (SPC) examinations indicated that the national average failure rate in Swaziland primary schools was about 16 percent, especially in the Shiselweni and Lubombo regions of Swaziland. According to the Ministry of Education and Training, in Swaziland through the Education Management Information System (EMIS) (2012), if failure rate exceeds 10 percent, it becomes worrying for the state. The introduction of the Swaziland Education and Training Sector Policy (2011) was to reduce the failure rate to 5 percent and to develop a policy on repetition. The quality of education depends on the teachers as reflected in the performance of their duties (Ncube, 2013). This suggests that children's academic performance is a direct reflection of the teachers' effort. On the contrary, teachers have their own perceptions with regards to poor academic performance at grade seven in the Shiselweni region of Swaziland. This became the crux of this study. Magagula (2013) posited that only 75 percent of learners enrolled at primary school are able to complete their education. Thus, 25 percent of the students do not complete their education. Magagula also observed that only 50 percent of learners are able to complete their primary school, with many taking as long as 12 years to do so. There is evidence of high dropout rate because learners do not complete their education. This indicates that a lot of learners dropout of school. 
The perceptions of primary school teachers on the causes of high failure rate at grade 7 level in the

Table 1 Percentage Failure rate in the region by sex and year from 2009 to 2012.

\begin{tabular}{|l|l|l|l|l|l|}
\hline Gender & Year & Hhohho & Lubombo & Manzini & Shiselweni \\
\hline Female & $\mathbf{2 0 0 9}$ & 13.2 & 15.7 & 13.3 & 15.9 \\
\hline \multirow{4}{*}{ Total Female } & $\mathbf{2 0 1 0}$ & 12.4 & 13.4 & 11.8 & 15.0 \\
\cline { 2 - 6 } & $\mathbf{2 0 1 1}$ & 12.0 & 14.4 & 12.0 & 14.0 \\
\cline { 2 - 6 } & $\mathbf{2 0 1 2}$ & 12.1 & 16.6 & 10.0 & 15.2 \\
\hline Male & $\mathbf{2 0 0 9}$ & 12.4 & $\mathbf{1 5 . 0}$ & $\mathbf{1 1 . 8}$ & $\mathbf{1 5 . 0}$ \\
\hline & $\mathbf{2 0 1 0}$ & 16.8 & 20.9 & 18.0 & 20.5 \\
\cline { 2 - 6 } & $\mathbf{2 0 1 1}$ & 16.5 & 16.9 & 15.9 & 19.6 \\
\cline { 2 - 6 } & $\mathbf{2 0 1 2}$ & 17.5 & 18.3 & 16.2 & 19.1 \\
\hline \multicolumn{2}{|l|}{ Total Male } & $\mathbf{1 7 . 1}$ & $\mathbf{1 8 . 7}$ & 14.4 & 21.0 \\
\hline Total & 14.9 & 16.9 & 14.1 & $\mathbf{2 0 . 0}$ \\
\hline
\end{tabular}

Table 1 above contextualises the problem, considering that it outlines the grade seven performances in the other three regions of Swaziland. The results from the last four years indicated that the national average failure rate in Swaziland primary schools was about 16 percent (Ministry of Education and Training [MoET], 2012). Table 1 indicates that Lubombo and Sheselweni accounted for the highest failure rates in the country. These two regions are associated with relatively high poverty levels than Manzini and Hhohho. However, national educational resources are equitably distributed.

Despite the launch of Free Primary Education by the government of Swaziland in 2010, high failure rate have been observed in some primary schools especially in the Shiselweni region. It is against this background that the research was conducted to determine the perceptions of the teachers on the causes of high failure rate at grade Seven level in the Shiselweni region of Swaziland.

The results of the study were used in designing appropriate intervention strategies to curb the high failure rate in the Shiselweni Region which will assist in fighting economic and social problems. This study addresses the following research questions:

1. What do the teachers say are the environmental factors contributing to high failure rate at the Grade 7 level in the Shiselweni region of Swaziland?

2. Explore the teachers' perceptions on teacher factors which are responsible for high failure rate at Grade 7 level in the Shiselweni region of Swaziland.

3. How do the teachers perceive the pupil characteristics as being responsible for the high failure rate at the Grade 7 level in the Shiselweni region of Swaziland?

4. What are the contributions of parents/ guardians to the causes of high failure rate at the Grade 7 level in the Shiselweni region of Swaziland?

\section{LITERATURE REVIEW}

The causes of high failure rate at grade seven are well documented. In this study, the review of literature took a global perspective and was done under specific emerging themes. Concerns have been expressed about the causes of this catastrophe in the education system of Swaziland. These causes are the environmental factors, teacher factors, pupil factors and parental factors. In addition, there are school principals' strategies to curb the high failure rate in the schools. Although these causes have been widely accepted, the study has been challenged with disregards the perceptions of the teachers on the causes of high failure rate in the Shiselweni region of Swaziland.

\section{EDUCATIONAL RESOURCES AT HOME}

Boethel (2003) stated that the causes of high failure rate were the lack of provisions of learning experiences in the home. Other causes included learner absenteeism (Brophy 2006), poverty (Creswell, 2003), low socio-economic status of the parents (Mbugua, Kibet, Muthaa \& Nkonke 2012) and the inaccessible areas (Marope, 2012). The study wanted to find out also; if absenteeism, poverty and low socio-economic status of the parents were contributing to high failure rate in the present study.

\section{DISTRIBUTION OF FACILITIES AND RESOURCES}

Substandard classrooms were a factor on the reasons for the high failure rate at primary school level (Haidary 2013). Other factors were lack of learning facilities (Etsey, 2005; Mapolisa \& Tshabalala 2014), the urban-rural gap of the distribution of teachers (Mulkeen \& Chen, 2008), the lack of teaching personnel due to 
sick and maternity leave (Legotlo, Maaga \& Sebego, 2002) and the unevenly distribution of the qualified and unqualified teachers (Steiner-Khamsi \& Simelane, 2010).

\section{THE TEACHER FACTORS CONTRIBUTING TO HIGH FAILURE RATES}

According to Sebates, Akyeampong, Westbrook \& Hunt (2010), teachers' absenteeism was associated with the high failure rate. However, Fonseca \& Conboy (2006), states that teachers are employed for the wrong reasons not for the teaching proficiency. Nahid (2012), states that teachers are stressed because of the

lack of income, lack of status and late payments. On the other hand, Mukisa, Mugisha \& Zeitlin (2009) stated that the poor performance was the result of the inadequate and lack of teachers' accommodation. Mapolisa \& Tshabalala (2014) declared that the result of the high failure rate was attributed to lower level of professional qualifications by the teachers, who were not confident with presenting some of the topics in their subject areas. Some teachers felt that it was not easy to source out information except from the students' textbooks available. In other words, they have limited knowledge of the subject matter (Ntho-Ntho, 2009 \& Paulsen, 2011) and some are not confident to teach in English (Khumalo, 2013). Steiner-Khamsi \& Simelane (2010) revealed that ill teachers do not report for work; therefore there is high rate of teacher absenteeism. HIV/AIDS learners were another cause of the high failure rate. They need the teacher's attention, yet the teacher is not trained to help sick learners. So the researcher wanted to find out if the teachers' factors were a contributory cause to high failure rate at primary school level.

\section{PUPILS' FACTORS CONTRIBUTING TO THE HIGH FAILURE RATE}

The causes of the high failure rate were instigated by the learners' absenteeism due to lack of nutritious food, poor attention (Rahamneh, 2012); incomplete homework, examination phobia, hyperactivity, learning disability, asthma, anaemia and hearing deficiency (Kamal \& Bener, 2009). However, Petersen (2009) revealed that the causes of high failure rate were due to the low level of interest in the schoolwork, spending too much time on television, cell phone, internet and idleness.

\section{THE PARENTAL FACTORS CONTRIBUTING TO HIGH FAILURE RATE}

Parents are also blamed for the high failure rate of learners. Cullingford \& Morrison (1999), World Bank (2006), Feinstein \& Symons (1999), and Litwin (1995), observe that lack of parental involvement was the cause of the high failure rate of learners. However, a different view was echoed by the Swaziland Government (2012) that teachers mentioned that parents should also use English as a home language. The government of Swaziland observed that learners fail because they are incompetent in the language of school (English). Moreover, Trochim, (2007) referred to this kind of environment as the "curriculum of the home". Another cause of the high failure rate was that the learners tend to defy female teachers yet they are always a majority in the primary schools with a minority of the male teachers (Ministry of Education, 2011).

\section{METHODOLOGYRESEARCH DESIGN}

The phenomenological design was adopted to examine teachers' perceptions on the causes of high failure rate at grade seven level in the Shiselweni region of Swaziland. This is a qualitative design. Burns \& Grove (2003) define research design as a "blueprint for conducting a study with maximum control over factors that may interfere with the validity of the findings". Qualitative research is a type of primary research in which the researcher collects first-hand information obtained directly from the participants in their natural setting. Its goal is to explore and understand a central phenomenon (Creswell, 2007). The qualitative design was implemented because the researchers wanted to find the phenomenon "failure rate" as to why it was particularly high at grade seven in the Shiselweni region of Swaziland as perceived by the teachers. The participants were interviewed in their natural setting. A phenomenological approach was relevant for the current study because in a phenomenological study participants are asked to describe their experiences as they perceive them. So the participants were asked to describe their experiences about the causes of high failure rate as they perceived them. For these reasons, the present researchers found the qualitative phenomenological design very appropriate for the current study.

\section{PARTICIPANTS OF THIS STUDY}

Six primary schools were randomly selected from a list of the 26 worst performing schools which were obtained from the Examination Council of Swaziland (ECS). Initially, purposive sampling was done where the researchers got a list of the worst performing from ECS. Later, simple random sampling was then used to select the actual participants. The aim for using this type of sampling was to ensure that each individual school has an equal chance of being selected. Henning (2004) defines random sampling as selecting information rich in cases

DOI: 10.9790/0837-2201035362 $\quad$ www.iosrjournals.org $\quad 55 \mid$ Page


for study in-depth, when one wants to understand something about those phenomena without needing or desiring to generalise to all such phenomena. The study targeted six grade seven teachers and the six principals from the purposively sampled worst performing primary schools in the Shiselweni region of Swaziland. The grade seven teachers were found to be the key informants for the study because they are directly involved in the teaching of the learners in the grade seven level.

\section{DATA COLLECTION INSTRUMENTS}

The researchers triangulated the data by employing the use of in-depth interviews, focus group discussions and documents analysis. According to Macmillan \& Schumacher (2006) triangulation is the crossvalidation among data sources, data collection strategies, time periods and theoretical schemes. Yin (2009) and Stake (2000) concur that triangulation is crucial to performing a phenomenological study reliably. Interview guides were developed for both the interviews and the focus groups. Documentary data was subjected to a document analysis rubric.Schuh \& Upcraft (2001) assert that interviewing is a valuable assessment tool because it allows the participant to share their experiences, attitudes and beliefs in their own words. So the interviews were conducted with the grade seven teachers and the school principals. Interviews were found relevant for the study because it allowed the participants to share their experiences and perceptions about the causes of the high failure rate at grade seven level in the Shiselweni region of Swaziland. It also helped the researchers to identify variables and relationships. It assisted the researchers to get deeper into the motivations of participants and their reasons for responding in the manner they did. The participants interpreted the world in which they lived and expressed what regarded as the causes of the high failure rate at grade seven level from their own point of view.In addition to the interviews, the focus group interviews were conducted with the grade seven teachers and the school principals. The focus groups encouraged the free flow of ideas. It is typically led by one moderator who in this case was the researchers. Two groups of grade seven teachers and the school principals were randomly selected by the researchers. Interviews lasted for about 1-2 hours each. All the participants of the study were considered key informants who provided data on their perceptions on the causes of high failure rate at the grade seven level in the Shiselweni region of Swaziland.Moreover, documents analyses were employed to find the causes of the high failure rate at grade seven level in the Shiselweni region of Swaziland. Documents analysis is considered as a primary source of data and may include manuscripts, charters, laws, files, letters, official publications, wills, newspapers, magazines, timetables and school policies (Cohen, Manion \& Morrison, 2005). The researchers used documents analysis to avoid the danger of relying only on the interviews. The documents used were the composite timetables, time books, scheme books, preparation books and test books. Bowen (2009) asserts that document analysis is often used in combination with other qualitative data collection instruments as a means of triangulation. The researchers used the documents to gain additional insight into the participants regarding their perceptions on the causes of high failure rate at grade seven level in the Shiselweni region of Swaziland. The data gathered through document analysis were used to scrutinise the themes that emerged from the data gathered through interviews and focus group meetings. The themes from document analyses were used to authenticate the themes that emerged from the interviews and focus groups.

Table 2: Documents and data analysed in the schools

\begin{tabular}{|l|l|}
\hline $\begin{array}{l}\text { Documents } \\
\text { selected }\end{array}$ & Data analysed \\
\hline Preparation Books & $\begin{array}{l}\text { Frequency of the lesson preparation, the structure } \\
\text { of the lesson preparation, activities for learners } \\
\text { and the usage of the learning materials }\end{array}$ \\
\hline Scheme Books & $\begin{array}{l}\text { Availability of the schemes of work, covered } \\
\text { syllabus and appropriateness of the teaching } \\
\text { methods }\end{array}$ \\
\hline Test books & $\begin{array}{l}\text { Number of tests per term, length of the tests, } \\
\text { types of questions }\end{array}$ \\
\hline $\begin{array}{l}\text { Composite } \\
\text { Timetables }\end{array}$ & Availability, no lesson clashes and its practicality. \\
\hline Time Book & Teachers absenteeism, leave, punctuality \\
\hline
\end{tabular}




\section{DATA ANALYSIS APPROACHES}

Data were first recorded and transcribed verbatim. As the study progressed, it were analysed, continually, refined and reorganised in light of the emerging results. Dawson (2002) argued that there are many different types of qualitative data analysis, and these include thematic analysis, comparative analysis and content analysis. For this study the thematic analysis was used because it was highly inductive in that the themes emerged from the data and not imposed by the researchers. The themes were interpreted and sorted through coding according to the objectives of the study. The researchers read all the data and sorted them through looking for units of meaning such as phrases, subjects of thinking, behaviour and patterns that appear regularly and important. All the transcriptions were regarded as "the truth" and each transcription was considered to contain a one-to-one correspondence between what was said orally and the printed word. For the documents analysis the researchers utilised the content analysis.

\section{CREDIBILITY AND DEPENDABILITY}

The issues credibility of the instruments are vital in establishing the truthfulness of findings (Neuman, 2000). In this study, to ensure credibility the open-ended questions for the interviews and focus groups were drafted against the objectives and research questions. The instruments were taken to experts to check their credibility. Data were collected from more than one group for the purpose of triangulation. It is worth noting that any type of triangulation strengthens the credibility and reliability of the findings of a study. Mason (1996), states that dependability involves the accuracy of the research methods and the techniques which are used. In this study a thematic approach was used to test dependability. A thematic approach according to Best and Kahn (2006), is a projective instrument which enables participants to unconsciously reveal themselves by projecting their internal feelings, attitudes, needs, values, or wishes to the external object. The use of the thematic approach was relevant for the study because it particularly helped in counteracting the tendency of participants to try to appear in their best light, to respond as they believe they should.

\section{RESULTS}

The results of the study are presented according to themes generated from interview items, focus group discussions and documents analysis which are guided by the research questions. Where participants were quoted verbatim, pseudonyms were used to maintain confidentiality.

Table 3: Biographic data of the teachers interviewed

\begin{tabular}{|l|l|l|l|l|l|l|l|l|}
\hline $\begin{array}{l}\text { Sr } \\
\text { no. }\end{array}$ & $\begin{array}{l}\text { Teacher } \\
\text { Name }\end{array}$ & $\begin{array}{l}\text { Gend } \\
\text { er }\end{array}$ & Age & $\begin{array}{l}\text { Professional } \\
\text { Qualificatio } \\
\text { n }\end{array}$ & $\begin{array}{l}\text { Designati } \\
\text { on }\end{array}$ & $\begin{array}{l}\text { Teaching } \\
\text { Experien } \\
\text { ce }\end{array}$ & $\begin{array}{l}\text { Name of } \\
\text { School }\end{array}$ & $\begin{array}{l}\text { Locatio } \\
\text { n of } \\
\text { School }\end{array}$ \\
\hline 1 & Abner & $\mathrm{M}^{1}$ & 45 & BA $^{3}$ & PST $^{7}$ & 20 years & School A & Rural \\
\hline 2 & Bernard & $\mathrm{M}^{2}$ & 44 & B.Ed. $^{4}$ & Principal & 2 months & School A & Rural \\
\hline 3 & Cecil & M & 27 & PTD $^{5}$ & PST & 4 years & School B & Rural \\
\hline 4 & Dumsani & M & 46 & B.Ed. & Principal & 6 years & School B & Rural \\
\hline 5 & Eric & M & 40 & PTD & PST & 10 years & School C & Rural \\
\hline 6 & Faro & M & 54 & PTD & Principal & 10 years & School C & Rural \\
\hline 7 & Gertrude & F & 35 & PTD & PST & 15 years & School D & Rural \\
\hline 8 & Happy & F & 48 & BA & Principal & 5 years & School D & Rural \\
\hline 9 & Ivy & F & 27 & PTD & PST & 3 years & School E & $\begin{array}{l}\text { Semi- } \\
\text { urban }\end{array}$ \\
\hline 10 & James & M & 58 & PTC & Principal & 10 years & School E & $\begin{array}{l}\text { Semi- } \\
\text { urban }\end{array}$ \\
\hline 11 & Kina & F & 30 & B.Ed. & PST & 5 years & School F & Rural \\
\hline 12 & Leonard & M & 59 & PTC & Principal & 30 years & School F & Rural \\
\hline
\end{tabular}

M1, Male

F2, Female

BA3, Bachelor of Arts Humanities + Post Graduate Certificate in Education

B.Ed.4, Bachelor of Education

PTD5, Primary Teachers' Diploma

PTC6, Primary Teachers' Certificate

PST7, Primary School Teacher 
The main purpose of the study was to investigate their perceptions on the causes of high failure rate at grade seven in the Shiselweni region of Swaziland. Data collected from the open ended interviews, focus group interviews and documents analysis were categorised in themes and analysed.

\section{The role of the home environment as a cause for high failure rate}

Under this theme, the results of the study showed that the majority of the teachers perceived the high levels of illiteracy in the community as a contributory cause to high failure rate of the grade seven learners because the parents do not have the capacity to assist their children with school work. Some teachers reported teenage pregnancy as one of the causes of high failure rate because a lot of learners drop out due to pregnancy. Some parents are reported to be negligent when it comes to taking care of their children's welfare as a result they engage in love relationships which causes them to fail at the end of their academic year. Most learners were reported to be orphans, who have no one to assist. Some were reported to be the heads in their households. Absenteeism was another cause of the high failure rate. Some learners do not come to school because they are engaged in the kucutsa (harvesting and preparing the drug) exercise. This was defined as the process when the children help their parents in preparing the dagga by harvesting it for market. At this time children do not attend school. Some learners were reported by the teachers not to be serious with school work because they fail and still continue with their education in South African schools.

\section{The role of the school environment as a cause for high failure rate}

The results of the study also indicated that all the schools presented a good and conducive environment for learning. They mentioned that children are provided with lunch. Teachers teach even during their spare time. There was good infrastructure like toilets, good classroom and play grounds within the schools which participated in the study. However, in one school the teachers complained of their principal that he was too lenient. As a result; teachers were free to do as they wished. They added that teacher absenteeism was rife in the school. This was perceived as one of the contributory factors to high failure rate at grade seven level because teachers do not spend their time at work.

\section{Swaziland education and training sector policy}

During the interviewing process, a majority of the teachers complained that they are not furnished with the education policy. As a result they did not know what was legal and illegal in the teaching profession. That included the banning of corporal punishment and class sizes. Teachers teach a large numbers of learners in small classrooms and this was reported to be a challenge to teachers.

\section{The teacher factors perceived to be responsible for high failure rate}

Some teachers reported that the causes of high failure rate in their schools are partly caused by the unavailability of computers in their schools. Others attributed the causes to the hiring of unqualified personnel who are deployed to teach grade seven learners. This, they argued, was caused by shortage of teachers in the schools especially the rural schools. A majority of the teachers blamed the TSC for not interviewing the teachers when they are employed. They perceived this as a cause of the high failure rate. In addition, the teachers complained of inadequate time for teaching the different subjects. They mentioned that they do not finish the syllabus. They are then forced to teach on weekends and holidays and yet the learners do not attend the classes, hence the high failure rate.

\section{The contribution of pupils' factors to failure rate}

The participants interviewed disclosed that one of the causes of the high failure rate was that the learners do not value education. As a result they rarely do their homework. The participants blamed the parents for negligence, illiteracy and for failure to motivate their children on the value of education. A few learners own cell phones, as a result there was not much impact brought by the availability of these gadgets.

\section{Lack of parental support as a factor for high failure rate at grade seven}

All the participants interviewed, reported that the cause of the high failure rate was lack of parental involvement in the education of their children. It was revealed that the parents were either dead or just negligent. The participants reported that some parents/guardians do not attend school meetings and open days. The study also noted that it was deplorable to find out that some learners were orphans, so there was no one to care for them and their educational needs.

\section{Suggested strategies to combat high failure rate at grade seven level in Shiselweni}

During the interviews, participants suggested some strategies which they could employ to improve the academic results of their schools. A majority of participants suggested that there is need to select dedicated 
teachers to teach the grade seven learners. Other school, principals mentioned that they needed to discuss staffing issues with the relevant personnel and come up with a working solution to avert the situation. School principals demonstrated awareness of the schools' vision and they were working towards fulfilling it.

\section{Administration related challenges}

However, they mentioned some challenges that they encountered as principals of the schools. They complained about the absence of resources especially the libraries. Other challenges mentioned were the nonexistence of English speaking people in the schools, dearth of security fences, long distances learners travelled from home to school, poverty, and delayed school fees payments by the government and the numerous visits by the school inspectors. All the challenges were found to impede the working progress of the school resulting to high failure rate.

\section{Documents analysis}

The researchers analysed the documents by taking a closer look at the selected data and performed a coding and category construction based on the data's characteristics, to uncover the themes pertinent to the research questions, as presented in Table 2 and 3.

Table 4: The analysed documents collected from the interviewed teachers.

\begin{tabular}{|l|l|l|l|l|}
\hline $\begin{array}{l}\text { Participants } \\
\text { (Not their real names) }\end{array}$ & School Name & $\begin{array}{l}\text { Daily Preparation } \\
\text { Book }\end{array}$ & Scheme Book & Test Book \\
\hline Abner & School A & A1 & NA2 & A1 \\
\hline Cecil & School B & A1 & NA2 & NA2 \\
\hline Eric & School C & A1 & NA2 & NA2 \\
\hline Gertrude & School D & NA2 & NA2 & NA \\
\hline Ivy & School E & NA2 & NA2 & NA2 \\
\hline Kina & School F & NA & A3 & NA2 \\
\hline
\end{tabular}

A1, Available but incomplete

NA2, Not available

NA, Forgotten

A3, Available but meaningless

Table 5. Documents analysed from the interviewed principals

\begin{tabular}{|l|l|l|l|}
\hline Participant & School & Composite time table & Time book \\
\hline Bernard & School A & $\mathrm{A}^{1}$ & $\mathrm{~A}^{2}$ \\
\hline Dumsani & School B & $\mathrm{A}$ & $\mathrm{A}^{2}$ \\
\hline Faro & School C & $\mathrm{A}$ & $\mathrm{A}^{2}$ \\
\hline Happy & School D & $\mathrm{A}^{1}$ & $\mathrm{~A}^{2}$ \\
\hline James & School E & $\mathrm{A}$ & $\mathrm{A}^{2}$ \\
\hline Leonard & School F & $\mathrm{A}$ & $\mathrm{A}^{2}$ \\
\hline
\end{tabular}

$\mathrm{A}^{1}$, Available but data not complete

A, Available

$\mathrm{A}^{2}$, Available with false information

Table 4 and 5 illustrate the participants whose documents were analysed, the names of schools where they teach and the pertinent information about the participants' documents. The information found from the documents assisted the researchers to get a deeper understanding of the experiences and causes of the high failure rate at grade seven in the Shiselweni region of Swaziland.

\section{DISCUSSION}

The results showed that the causes of the high failure rate can not be attributed to a single factor, but to a multiplicity of factors which are all related. The non conducive environment both at home and at school play a key role in promoting high failure rate of learners at grade seven level in the Shiselweni region of Swaziland. For instance, Woodhead, Oates and Keynes (2007) asserted that family poverty has been found to adversely affect the children's health, intellectual capabilities, academic achievement and behaviour. Similarly, Marope (2012) proposed that the Shiselweni region was the poorest region of Swaziland. It is mainly rural and have the lowest access to education. This was also confirmed by the results of this study. Although a majority of the teachers were complaining about their unawareness of the Swaziland education and Training Sector Policy 
which was labelled as one of the causes of the high failure rate, the results of this study revealed that the participants were not mindful of the goals of the policy. They were teaching big number of learners per class which was against the policy. Some were found to be effecting corporal punishment contrary to the policy. In addition to that, the study also showed that both children and teachers travel long distances to school. This affected both teaching and learning. This is learners come late, weary and hungry therefore teaching them becomes impossible, consequently, they underperform or literally fail.The study also blamed untrained or inexperienced teachers for the high failure rate in the schools. In the Shiselweni region, there are many inexperienced teachers as well as unqualified teachers who teach at grade seven level. The study also observed that some teachers do not finish the syllabus yet at the end of the year the learners sit for the same external examination from the Examination Council of Swaziland as that written by learners who completed the syllabus. According to Magagula (1990), after independence in 1968, Swaziland like other developing countries was faced with numerous educational challenges like the shortage of trained teachers. These findings agree with those of the World Bank (2010) study which showed that in Swaziland; about 20 percent of teachers in rural areas are unqualified. Participants felt that high failure rate may be attributed to TSC which employs teachers randomly. The study discovered that teachers do not go through a formal interview when they are hired. The result is; incompetent teachers find their place in the classroom; hence poor results at grade seven level.

Some participants attributed the causes of high failure rate to pupils themselves. Petersen (2010) observed that the learners' low level of interest in school work, absenteeism, spending too much time on television, cell phones and internet, peer pressure and idleness were factors contributing to high rate in schools. In this study one participant revealed that some schools in Swaziland have been found to record high failure rate because of the extreme use of social media by the learners, drug abuse, reluctance in doing school work and the learners not value education. Another observation was that parents also contribute to high failure at primary school level in the Shiselweni region of Swaziland. Joyce Epstein's Theory of Overlapping Spheres of Influence (1995) identified three major contexts in which a child learns and grows. That is the school, family and community. Participants revealed that parents must be in a position to assist the learners. They must come to the teachers at school to discuss the academic progress of the learners. Hence, this theory fits very well in explaining the causes of high failure rate in the Shiselweni region of Swaziland.Although the participants attributed the causes of the high failure rate of the grade seven learners in the Shiselweni region to a number of factors; some school principals remained optimist. They suggested some mitigation strategies to the prevailing challenges encountered in the schools. Some reported that they were in a process of building a library so that learners can read to improve their English language. Some were involving the teachers in decision making processes. They called this distributed leadership. They hold numerous staff meeting to discuss problematic issues which pertains the school. Some said that they want to construct pre-schools, which they thought was going to improve the academic performance of the school. According to Kormla (2012), regular academic meetings with teachers, observation of classroom teaching, teaching a class when the class teacher is absent, team teaching, checking students' assignments and extra tutorials were seen as key mitigatory strategies to curbing high failure rate.

\section{CONCLUSION}

In conclusion the following variables were found to be most significant causes for the high failure rate at grade seven level in the Shiselweni region of Swaziland. Teachers in Swaziland in the Shiselweni region perceived the causes of the high failure rate as consistent to those reported globally. They mentioned that the causes were environmental, teachers' factors, pupils factors, parental factors and the school principals suggested similar strategies to curb the high failure rate in their schools.

\section{RECOMMENDATIONS}

Based on the observations from this study, this study recommends that teachers need to consider methods which will bring about a good relationship and interaction between them and the learners. The study observed that learners were not close to their teachers. Moreover, learners should be encouraged to participate in extra-mural activities so that they can build self-confidence and positive self-esteem, which is hoped to improve the academic performance of the learners. In addition, teachers should desist from unnecessary absenteeism. Learners should create clubs to encourage one another about the value of education. Parents should be involved in the learning of their children. The school principals should model the life they would like their teachers to portray. Moreover they should invite in-service personnel to come and assist teachers who seem to lack some basic teaching skills. The Ministry of Education should organise in-service workshops and make sure that the resources are distributed equitably in all the schools of Swaziland. 


\section{REFERENCES}

[1] Boethel, M. (2003). Diversity: School, Family and Community Connections.In A. Averett, J. Buttram, D. Donnelly, C. Jordan, M. Myers, E. Orozco \& L. Wood (Eds.), National Centre for Family \& Community Connections with Schools (pp.18-19). Austin, Texas: Southwest Educational Development Laboratory (SEDL).

[2] Bowen, G. A. (2009). Documents Analysis as a Qualitative Research Method.Qualitative Research Journal, 9(2), 27-40.

[3] Brophy, J. (2006). Grade Repetition Education Policy Series No.6. Paris, International Academy and IIEP.

[4] Burns, S. N. \& Grove, S. K .,(2003). The Practice of Nursing Research Conduct, Critique and Utilization ( $4^{\text {th }}$ ed). W B. Saunders: Philadelphia, Pennysylvania. USA.

[5] Cohen, L. \& Manion, L. (1989). Research Methods in Education. London: Routledge.Conger, R. D., Conger, K. J., Elder, G. H., Lorenz, F. O., Simons, R. L., \& Whitbeck, L. B. ～(1992). A family process model of economic hardship and adjustment of early adolescent boys.Child development, 63, $526-541$.

[6] Creswell, J. W. (2003). Research design: Quantitative, qualitative and mixed method approaches $\quad 2^{\text {nd }}$ Ed. Sage Publication Ltd, USA.

[7] Cullingford, C. \& Morrison, M. (1999). Relationships between parents and schools: A case study. Educational Review, 51(3): 253-262.

[8] EMIS(2010). Review of Education Management Information Systems in Swaziland. Authored:

[9] Epstein, J. L. (1992). School and Family Partnership; in Encyclopedia of Educational Research $6^{\text {th }}$ Ed., ed. M Alkin (New York): Macmillan, 1141.

[10] Epstein, J. L. (1995). School/ Family/ Community Partnership: In Encyclopedia of Educational Research 6th Ed., ed. M Alkin (New York): Macmillan, 1141.

[11] Etsey, Y. K. A., Amedahe, F.K. \& Edjah, K. (2005). Do private primary schools perform better than public schools in Ghana.Unpublished paper. Department of Educational Foundation, University of Cape Coast, Cape Coast.

[12] Etsey, K. (2005). Cause of Low Academic Performance of Primary school pupils in the Shama Submetro of Shama Alanta: East Metropolitan Assembly (SAEMA) in Ghana (Doctorial thesis), University of Cape Coast, Ghana.

[13] Feinstein, L. \& Symons, J. (1999). Attainment in Secondary School. Oxford Economic Papers, 51, 300-321.

[14] Haidary, A. (2013). Controversy over Grade Repetition (Published Doctorial thesis), KarlstadsUniversity, Afghanistan.

[15] Henning, E. (2004). Finding your way in qualitative research. South African Journal ofPsychology: Van Schaik ISBN: 0-627-02545-5.

[16] Kamal, M. \& Bener, A. (2009). "Factors contributing to school failure among school children in very fast developing Arabian Society." Oman Medical Journal 24 (3): 212 - 7.

[17] Khumalo, T.F. (2013). Effective Delivery of Public Education Services. A review by AfriMap and the Open Society Initiative for Southern Africa: Open Society. Kormla, E. (2012). Principals' strategies for Improving the Academic Achievement ofStudents of Disadvantaged Rural Junior High Schools in Ghana. School of Education: Edith Cowan University.

[18] Legotlo, M. W., Maaga, M. P. \& Sebego, M. G. (2002). Perceptions of stakeholders on causes of poor performance in grade 12 in a province in South Africa. South African Journal of Education, 22: 113-118.

[19] Litwin, M. S. (1995). How to measure Survey Reliability and Validity.Messerschmidt, D. A.

[20] Magagula, C. (1990). Implementing Educational Policy, in Swaziland. World bank Discussion Paper, 88, Washington, DC. The World Bank.

[21] Magagula, C.M. (2012-2013). Vice Chancellor's Message. Report of the Vice Chancellor 2012-2013. Kwaluseni: University of Swaziland.

[22] Mapolisa, T. \& Tshabalala, T. (2014). Perception of Teachers on causes of Poor Performance of Pupils out ordinary level public Examinations in Zimbabwean Rural Secondary Schools: A case study of Nkayi District. International Journal of Innovation and Applied Studies 8, 158-167.

[23] Marope, M. (2010). The education stystem in Swaziland: Training and skills development forshared Growth and competitiveness. Washington DC: Library of Congress Publication Data.

[24] Mason, J. (1996). Qualitative Research. London: SageMbugua, Z.K., Kibet,K., Muthaa, G. M. \& Nkonke, G. R. (2012). Factors contributing to students poor performance in mathematics at Kenya 
certificate of secondary education in Kenya: A case of Baringo County, Kenya. American International Journal of contemporary research, 2, 87-91.

[25] McMillan, J. H. \& Schumarcher, S. (2010). Research Based Inquiry. (6 $6^{\text {th }}$ ed) Boston: Pearson Education.

[26] Ministry of Economic Planning (2012). Swaziland Millennium Development Goal Progress Report, Government of Swaziland, Swaziland, Author:

[27] Ministry of Education and Training (2011).The Swaziland Education and Training Sector Policy. Mbabane, Swaziland.

[28] Mukisa, W.N. Mugisha, F. \& Zeitlin, A. (2009). Primary Education Service delivery: Pupil erformance and perceived challenges in Uganda. The Centre for the Study of African Economies CSAE).

[29] Mulkeen,S. \& Chen, B. (2008). Student Retention in a Modular World- A Study of Student Retention UCD Entrants 1990-2007. Dublin: university College Dublin.

[30] Nahid, N. A. (2012) .Teachers: Emotional Intelligence, Job Satisfaction, and Organizational Commitment, Journal of Work place Learning, Vol. 24 Issue: 4, pp. 256 - 269.

[31] Ncube, A. (2013). Students' failure, a Shared Blame in Zimbabwean Secondary Schools- The Way Forward. International Journal of Science and Research (IJSR) ISSN (Online): $\quad$ 2319-7064.

[32] Newman, L. W. (2000). Social Research Methods: Qualitative \& Quantitative Approaches $\left(4^{\text {th }} \quad\right.$ ed.), London: Allyn \& Bacon.

[33] Ntho-Ntho, A. M. (2009). The Perceptions of Educators on Factors contributing to Grade repetition in Lesotho Primary Schools (Doctoral thesis, University of Pretoria, South Africa).

[34] Paulsen, M. B. (2011). Inspiring Teaching: Carnegie Professors of the year speak. [Review of the book Inspiring Teaching: Carnegie Professors of the Year speak by J. Roth (ed)]. The Journal of Faculty Development 15, 35-36.

[35] Petersen , L. J.(2010). Parents and Education Perceptions of Factors Influencing High rate of Academic Failure of Learners in Clarke Estate Primary Schools. (Doctoral thesis), University of Western Cape, South Africa.

[36] Rahamneh, K. (2012). Reasons For The Low Academic Achievement Among The Students Of The Main Stages In Selected Schools In The Province of Al-Balqa. Ozean Journal of Social Sciences, 5(1), 36-39.

[37] Schuh, J. H. \& Upcraft, M. L. (1996). Assessment In Students Affairs: A Guide ToPractitioners. San Francisco: Jossey-Bass.

[38] Sebates, R., Akyeampong, K., Westbrook, J. \& Hunt, F (2010). School dropout: Patterns, causes, changes and policies.Vienna: Paper commissioned for the EFA Global Monitoring Report 2011, The Hidden Crisis: Armed Conflict and Education.

[39] Stake, R. E. (2000). Qualitative research: Studying how things work. New York, NY: The Guilford Press.

[40] Steiner-Khamsi. (2009). Real Teacher Shortage in the Krygyz Republic. A focus on Teacher Quality Bishkek: Unicefkrygyzstan.

[41] Trochim, W. M. (2007). The research methods knowledge base ( $3^{\text {rd }}$ ed.). Web centre for social research methods,:http://social researchmethods.net $/ \mathrm{kb} / \mathrm{htm}$.

[42] World Bank. (2006). Swaziland Achieving Education for All: Challenges and Policy Directions, Africa Region, 11-12.

[43] Yin, R. K. (2009). Case Study Research: Design and methods ( $4^{\text {th }}$ ed). Thousand Oaks, CA: Sage Paris.http://www.unesco.org/iiep. 